Received: 26/05/2019

Revision: 07/11/2019

Accepted: $15 / 11 / 2019$

OnlineFirst: $13 / 01 / 2020$

\title{
The Influence of Reflection in an Introductory Security Course: A Single Case Study
}

\section{Eric J. Russell}

Assoc. Prof., Utah Valley University Department of Emergency Services, USA, eric.russell@uvu.edu

\section{Jamie L. Russell}

Asst. Prof., Utah Valley University Department of Nursing, USA, jamie.russell@uvu.edu

Christian O. Lindquist, Jr.

Asst. Prof., Utah Valley University Department of Emergency Services, USA, chrisl@uvu.edu

Rodger E. Broomé

Utah Valley University Department of Emergency Services, USA, broomero@uvu.edu

Kevin P. McCarthy

A Utah Valley University Department of Emergency Services, USA, kmccarthy@uvu.edu

The purpose of the study was to ascertain how online asynchronous security coursework influenced learner's understandings by analyzing their end-of-course reflective writings. Following a qualitative single case study protocol, the researchers set forth to discover how a semester-long asynchronous online security course influenced students. The study took place at a public four-year university located in the Western United States. The 12 participants involved in this study all enrolled in and completed an introductory asynchronous online homeland security class either as part of their major or as a global/intercultural elective. From the data analysis three overarching themes emerged, (a) realization of responsibility and mission, (b) appreciation for new understandings, and (c) new areas of curiosity. The findings of this study begin a dialogue on what specific themes need to be considered when constructing future security and emergency management course offerings in academia.

Keywords: security education, reflection, asynchronous, online, case study

Citation: Russell, E. J., Russel, J. L., Lindquist Jr, C. O., Broome, R. E., \& McCarthy, K. P. (2020). The Influence of Reflection in an Introductory Security Course: A Single Case Study. International Journal of Instruction, 13(2), 315-328. https://doi.org/10.29333/iji.2020.13222a 


\section{INTRODUCTION}

Discovering the influence reflection had on students in a semester-long asynchronous online security course was the focus of this qualitative single case study. The course is offered as part of an emergency services administration bachelor's program at a University in the Western United States. The majority of learners taking this specific course are emergency services majors. However, in recent years the course has gained popularity with learners from other majors at the University who chose to enroll in the class as a global/intercultural elective option.

The central question guiding the study asks how an introductory asynchronous online security class influenced students; specifically, what in their own reflective writings were some "eureka" moments and takeaways from the coursework. To conduct the study, the researchers used the participants end-of-course reflections to glean an understanding of the influence the coursework had on the learners. The study focuses on reflection because past research has shown the reflective process to be where growth in understanding occurs (Mezirow, 1990; Moon, 1999). The participants in the study were all juniors and seniors majoring in different undergraduate disciplines. Individuals taking this specific course who were not emergency services majors, opted to take the course as an upper-division global/intercultural engagement elective from a list of 64 individual university catalog global/intercultural classes.

The specific course used in this research project explored current issues regarding security at the international, national, regional, state and local levels including global history and evolution of security, particularly as they relate to terrorism, disasters, and protections of peoples and infrastructure. In addition, the course introduced how international and national security topics impact state and local public safety agencies. Throughout the course, learners engaged in discussions pertaining to security, constructed briefings involving different nations as they relate to security, read multiple historical and contemporary security articles, completed reading quizzes, and finished the course with a final exam as well as a comprehensive reflective assignment on the overall experience.

Currently, there are over 300 universities throughout the United States offering undergraduate and graduate courses, certificate programs, degree programs in dozens of different areas within the security and emergency management framework (FEMA, 2018). Though these degrees may focus on particular areas within security and disaster management, they all seem to offer introductory and fundamental courses. Therefore, understanding the influence such introductory courses have on learners seems to be a need within security academia. Specifically, as Mezirow, (1990) argued, changes in deeper meaning and understanding occur can be seen in the reflective process; therefore, a need exists to focus on, and make meaning of, the results of a learner's reflection. In particular, because certain introductory classes can influence those choosing to take a course simply as an elective, into changing their major because of how interesting and impactful the learning experience (Hoisch \& Bowie, 2010). 


\section{LITERATURE REVIEW}

Security and disaster education in the United States primarily focuses on the all hazard response aspects associated with the United States Department of Homeland Security (DHS). DHS itself is a large bureaucracy that spans dozens of agencies and operations ranging from law enforcement, protection services, and emergency response to counterfeiting and human trafficking (Borja, 2008). For example, under the purview of DHS exists agencies such as the United States Coast Guard, the United States Secret Service, and the National Fire Administration. The conceptual idea of DHS was to create a department within the United States Federal Government that could encompass an all-hazard protection model. Thus, it became a single entity that could directly plan for, respond to, and recovery from any natural and human caused disasters. The vision for DHS was to transcend the outdated and cumbersome United States civil-defense model of the Cold War Era (Borja, 2008).

Empirical works that identify the need to understand how homeland security course offerings influenced university students formed this literature review. A noteworthy discovery in the literature was the impact emergency and security curricula and education had on students (Russell \& Fisher, 2014). The literature review begins with an overview of introductory courses within academia. Then the review offers a delineation of security education. The review then continues by offering a snapshot on the use of reflection in education, so as to tie into this study's use of end-of-course reflections in order to gain a better understanding of the influence the coursework had on participants.

\section{Introductory Courses}

The purpose of introductory courses within academic majors is to establish a basic understanding of a particular subject (Chesley et al., 2018; Goodyear, 2015). A properly designed introductory course incorporates the subject-matter that grounds a particular area of study in a way that sparks curiosity and a desire to know more (Goodyear, 2015; Gurung et al., 2016). This is also the case for non-academic majors seeking out interesting electives and general education opportunities (Gurung et al., 2016). Stimulating introductory courses can influence recruitment of students by inspiring them to change their major by introducing new theories and areas of knowledge (Hoisch \& Bowie, 2010).

Well-constructed introductory courses contribute to student success by providing a basic foundation of understanding on which to build upon (O'Neill \& Noonan, 2011). Introductory coursework needs to spark critical thinking and reflection on the subject matter (Burbach, Matkin, \& Fritz, 2004; Young \& Warren, 2011). As Schön (1987) argued, it is in the reflective process, where the learner thinks about thinking, that a deeper understanding and retention occurs.

Introductory courses within specific academic majors should share basic characteristics and subject matter across academic institutions. For example, an introductory course in psychology would include coursework on Wilhelm Wundt or in Peter Drucker in management. However, for introductory courses in homeland security there are still disagreements as to what subjects constitute the academic major (Bellavita \& Gordon, 2006). 


\section{Security Education}

Since the inception of modern security, both practitioners and academics have struggled to define what it is (Bellavita, 2008; Noftsinger, Newbold, \& Wheeler, 2007). Though this lack of a specific definition may seem like a problem to some, to others within academia it is an opportunity to approach the subject matter from different perspectives (Caruson \& MacManus, 2006). For instance, some institutions may choose to focus areas such as legal framework and constitutional issues, others terrorism or law enforcement, and for some, emergency response or cyber security (Bullock, Haddow, \& Coppola, 2011). Regardless of where one eventually decides to focus, two things seem to always need addressing: (a) the historical evolution of security, and (b) the role that the security bureaucratic apparatus plays within society. These two areas are common within introductory security courses throughout higher education (Comiskey, 2015).

According to the National Research Council (2005), there is a need to offer security focused courses throughout all disciplines and majors. The claim of the National Research Council (2005) seemingly creates a gap that needs to be addressed, particularly, a need for academia to understand how such security course offerings influences learners (Drabek, 2009; Russell \& Fisher, 2014). Drabek (2009) argued that studying security and disaster management increased broad societal resilience in the face of tragedy.

The research of Russell and Fisher (2014), discovered that students who attended a semester-long security class reflected that there was an "importance of homeland security education" (p. 23). This study builds upon the work of Russell and Fisher (2014) in order to discover why the field of study is viewed as important by understanding the specific influences the coursework had on students. Gleaning such an understanding of these influences holds possibilities for strengthening introductory security course offerings throughout academia.

The works of Drabek (2009), as well as Russell and Fisher (2014) suggest there is a need for academia to better understand how security coursework influences learners. Meaning, what are learners taking away from their studies beyond a grade. The works of Drabek (2009) as well as Russell and Fisher (2014), seem to reveal why studying local, national, and international security is important; however, there is still a need to understand how specific courses influence the understanding of undergraduate learners. Looking at the reflective works of learners that attend such security classes creates a pathway for understanding the influence of the coursework.

\section{Reflection in Education}

An avenue for strengthening a learner's ability to retain information is through the use of reflection (Dewey, 1938/2007). The reflective process gives the learner what Dewey (1938/2007) refers to as a secondary experience of one's learning. Therefore, it seems refection can improve the learner's understanding of homeland security coursework. Moreover, reflection has the potential to transform the way learners retain information beyond the classroom (Mezirow, 1990). 
According to Pelfrey \& Kelley (2011), security education's greatest attribute is equipping students with the ability to execute multifaceted, cognitive assignments. One way to accomplish this is through the use of reflection (Kiltz, 2009). Kiltz (2009) argues that reflection is a part of developing a learner's ability to think critically and make decisions. Thus, academia can strengthen a learner's critical thinking skills in part through the use of reflective assignments (Szenes, Tilakaratna, \& Maton, 2015).

At present, many students enrolled in university level security courses are practitioners in their field. As it is with other academic disciplines, adult learners have different expectations than the traditional learner and are identified as non-traditional students (Hughes, 1983). Russell and Fisher (2014) assert that when teaching these nontraditional students that are practitioners in security and emergency services career fields such as law enforcement, fire-rescue, and emergency medical services, it becomes necessary to follow adult-learning models. Course content and assessment associated with non-traditional learning needs to bridge academics with the practitioner experiences (Goldberg, 2012). Maxfield and Fisher (2012) posit that reflection and journaling are critical to the success of the non-traditional student, allowing the practitioner to ponder the coursework while linking it to their profession. Additionally, Maxfield and Fisher (2012) established that the traditional student relates their learning to future possibilities, while the non-traditional student relates experiences to learning.

When looking at an individual's thoughts and actions, a metacognitive process connects both thought and action, which must be reconciled prior to progressing and fostering additional thought and action. Kemmis (1985) stressed that reflection is both an inner process that looks at the person's thoughts as well as an outer process that looks at the situation. Moon's (1999) argument was that the highest level of deep learning is defined as one's ability to attain meaningful reflection. The work of Maxfield and Fisher (2012) advanced the position of reflection to argue that affective learning has been linked to learning and understanding at higher levels.

A review of the literature on reflection types offers the differences between single-loop reflection and double-loop reflection. Brockbank and McGill (1998) suggest single-loop reflection is centered on tasks and design of the process. Courtney, Croasdell, and Paraadice (1998) posit a single-loop is a lower level of reflection, because it is based on keeping rules and error correction. Courtney et al. (1998) described the double-loop reflection as a higher level versus the single-loop reflection because it focuses on the evaluation of the experience and the possible variations of the experience [emphasis added]. In addition, Goldberg (2012) suggests "reflective learning can be a valuable teaching practice in homeland security and emergency management programs where there is also a strong connection between experiential learning (practitioner experiences) and course learning objectives" (p. 68). Therefore, particularly for non-traditional learners that are professionally affiliated, it seems important to provide a venue for them to reflectively synthesize their course takeaways with their real-world experiences. These reflections seem to offer academia a pathway for understanding the influence such courses have on learners. 


\section{METHOD}

The study setting took place at state university located in the Western United States. The researchers employed a single case study qualitative design to conduct the study (Kennedy, 1979; Seawright \& Gerring, 2008; Yin, 2018). The population used in this study consisted of $n=12$ undergraduate students; see Table 1 . The participants were all juniors and seniors, with 8 identifying as male and 4 identifying as female. To protect the anonymity of the participants, the only demographic information disclosed is Academic Year, Academic Major, and Gender Identity.

Table 1

The Participants of the Study

\begin{tabular}{llll}
\hline Participant & Academic Year & Academic Major & Gender Identity \\
\hline Participant 1 & Junior & Emergency Services & Male \\
Participant 2 & Junior & Emergency Services & Male \\
Participant 3 & Junior & Biology & Male \\
Participant 4 & Senior & Political Science & Female \\
Participant 5 & Senior & Emergency Services & Male \\
Participant 6 & Senior & Biology & Female \\
Participant 7 & Junior & Criminal Justice & Female \\
Participant 8 & Junior & Emergency Services & Male \\
Participant 9 & Junior & Criminal Justice & Male \\
Participant 10 & Junior & Biology & Male \\
Participant 11 & Junior & Criminal Justice & Male \\
Participant 12 & Senior & Biology & Female \\
\hline
\end{tabular}

\section{Sampling}

The researchers used a type of purposive sampling known as theoretical sampling (Corbin \& Strauss, 2008; Patton, 2002). The justification for using the purposivetheoretical sampling process is that it allowed for theoretical discovery involving data collection and analysis from a pre-selected specific group (Patton, 2002). The researchers chose to use theoretical sampling because this particular study focused on a pre-selected course made up of specific learners. The course consisted of $n=57$ students. The researchers relied on data saturation to determine the study's sample size (Fusch \& Ness, 2015; Mason, 2010). Saturation, as it pertains to qualitative research, involves data collection and analysis to a point where nothing new emerges (Fusch \& Ness, 2015; Mason, 2010). Saturation occurred in the data analysis with $\mathrm{n}=12$ participants.

\section{Data Collection}

Data collection consisted of multiple end-of-course reflective writing assignments obtained from students that took part in the online security course. Data retrieval time took less than one day. Prior to conducting the research, the researchers obtained permission from their University Institutional Review Board to proceed with this research study. To protect the study participants, the researchers removed any personal identifiers. The researchers followed a specific, systematic case study approach to 
collect and analyze the data, as well as establishing a secure database for data collection and storage to ensure data reliability (Patton, 2002; Yin, 2018).

\section{Data Analysis}

To construct the case study, the researchers used a pattern matching analytic technique based upon the writings of the study's participants (Yin, 2018). As mentioned earlier, protection and anonymity of the study participants was paramount. To confirm validity, the researchers triangulated data sources from multiple participants, had another researcher conduct an analysis for comparison and present the data in descriptive tables in the results section. To ensure data reliability, the researchers followed specific case study protocols and established a secure database for data storage (Yin, 2018).

To analyze the data the researchers developed case descriptions utilizing a systematic, hierarchical approach (Stake, 1995; Yin, 2018). The data analysis began with the researchers organizing and preparing the data for analysis, removing any personal identifiers of each of the participants to protect their anonymity and then reading the transcribed questionnaires to become familiar with the data. Each participant was assigned a "P" and then a corresponding number. To analyze the data the researchers used a hand-coding process that involved color-coding the data (Basit, 2003). The handcoding process allowed researchers to spend more time reading and rereading the data, color-coding different attributes and compiling notes and common themes based on the participants writings (Basit, 2003; Corbin \& Strauss, 2008). Using inductive reasoning, propositions were generated from the findings and reported in the discussion (Coyne, 1984; Kennedy, 1979; Yin, 2018). To present the findings in the results section the researchers developed narrative case descriptions, in table form, based upon the emergent themes in order to display and interpret the findings (Kennedy, 1979; Yin, 2018).

\section{FINDINGS}

The results of the data analysis converged to answer the central question guiding this research. As noted in the introduction of this article, the question asked how an introductory online security course influenced students? The reflective assignment that was used to conduct this study was an end-of-course open ended writing assignment. The specific assignment asked learners to write of their experiences throughout the course, addressing any "eureka" moments, takeaways, interest in subject matter, and memorable reflections. Emerging from a data analysis of the writings were 3 themes, (1) Realization of Responsibility and Mission, (2) Appreciation for New Understandings, and (3) Areas of Curiosity. The following tables present the themes and corresponding attributes in the words of the participants; see Tables 2, 3, and 4. 
Table 2

Realization of Responsibility and Mission

\begin{tabular}{ll}
\hline Participant & Attribute \\
P1 & "I have a better understanding of how current and even past issues and events" \\
P2 & "I have come to realize that homeland security is so much more than terrorist \\
attacks by violent extremist groups. \\
P3 & "I have gained a new respect for everyone behind the Department of Homeland \\
P4 & "I seem to have a better understanding of bureaucracy in government." \\
P5 & "I have gained a respect for the organizations that fall under the Department of \\
P6 & Homeland Security" \\
"I have come to understand that homeland security is more complicated than most \\
P7 & "Meople initially think" \\
P8 & "My impression of the responsibilities of Homeland Security prior to this class was \\
"When I started this course, I had no idea that there were so many branches that fell \\
P9 & under the department" \\
P10 & "Before taking this class, my knowledge of homeland security was superficial" \\
P11 & "I was simply unaware of all the agencies involved in homeland security" \\
P12 & "Homeland security is bigger than I thought it was"
\end{tabular}

Table 3

Appreciation for New Understandings

\begin{tabular}{|c|c|}
\hline Participant & Attribute \\
\hline P1 & $\begin{array}{l}\text { "I have a better understanding of how our government and homeland security } \\
\text { works and why it was created" }\end{array}$ \\
\hline P2 & $\begin{array}{l}\text { "I have a newfound desire to know more about homeland security policies and } \\
\text { practices" }\end{array}$ \\
\hline P3 & "This class opened my eyes to just how much danger there really is in the world" \\
\hline P4 & $\begin{array}{l}\text { "This course pointed out how complacent or very casual viewpoint I had develop } \\
\text { regarding government operations" }\end{array}$ \\
\hline P5 & $\begin{array}{l}\text { "I now understand that there is a background to each decision, and that each } \\
\text { threat has been carefully thought out by those who do their best to protect us" }\end{array}$ \\
\hline P6 & $\begin{array}{l}\text { "To me, homeland security is a big deal. To protect our country as a whole it } \\
\text { requires all departments to work together" }\end{array}$ \\
\hline P7 & "Until now I had no idea about of Homeland Security" \\
\hline P8 & $\begin{array}{l}\text { "I now have a better understanding that it's the responsibility not only of the } \\
\text { government, but of every citizen, to keep the homeland safe" }\end{array}$ \\
\hline P9 & $\begin{array}{l}\text { "I have this new appreciation for the complex system of our country's homeland } \\
\text { security, and how it has grown by leaps and bounds" }\end{array}$ \\
\hline P10 & $\begin{array}{l}\text { "I feel that I have become so much more aware of the lengths that the } \\
\text { government goes to in order to keep people safe" }\end{array}$ \\
\hline P11 & $\begin{array}{l}\text { "It is much clearer to me that we are in a constant struggle to better our nation's } \\
\text { security from threats" }\end{array}$ \\
\hline P12 & $\begin{array}{l}\text { "I feel more educated in regard to foreign affairs and the relationship of the US } \\
\text { with the rest of the world" }\end{array}$ \\
\hline
\end{tabular}

International Journal of Instruction, April $2020 \bullet$ Vol.13, No.2 
Table 4

Areas of Curiosity

\begin{tabular}{ll}
\hline Participant & Attribute \\
\hline P1 & "What interests me the most about homeland security would be terrorism \\
P2 & "One area that interests me is our border patrol" \\
P3 & "The area of homeland security that interest me the most is TSA" \\
P4 & "I find the controversy of border protection interesting" \\
P5 & "I think the concept that interests me the most is protecting the American people \\
from terrorist threats" & "The area of Homeland Security that interests me the most is Immigration and \\
P6 & Customs Enforcement" \\
P7 & "I think the part of Homeland Security that is the most interesting is Immigration \\
P8 & "I Bam fascinated by FEMA" \\
P9 & "The area of homeland security that interests me the most is that of the United \\
P10 & "Leates Coast Guard" \\
P11 & "I really enjoy cyber security because we are under constant threat in \\
cyberspace" & "The area of homeland security that interests me most is the prevention, and \\
P12 & strategy the US has against terrorism"
\end{tabular}

\section{DISCUSSION}

The learners drew deeper connections for themselves between their previously held perspectives on homeland security, the presented course content and synthesized a richer understanding of the topic. For instance, P4 stated "I wonder why we can't approach things like homeland security with a common goal and understating" (P4). In this instance, P4 is going beyond the coursework and thinking about the common needs of society. Another example was $\mathrm{P} 3$, who noted that homeland security is "essential to the lives of each person in this country" (P3). Again, as it was with P4, the learner went beyond the specific coursework and reflected on the needs of society.

As in any intellectual exploration, the learners had many explicit and tacit questions answered by the curriculum which also evoked new thoughts such as P11 stating, "I also feel a little more protected, and also a little less protected because my eyes were opened to the strengths and weaknesses of our countries security" (P11). This qualitative case study was able to provide insights regarding learners' takeaways, which were quite substantial and meaningful.

\section{Realization of Responsibility and Mission}

The students describe their pre-course narrow perspectives of the topic to contrast their end-of-course broadened views. For example, P12 stated "Homeland security is bigger than I thought it was" (P12). The breadth and scope of the DHS was initially seen as a faceless government bureaucracy. Through the class, many came to see the DHS as a complex governmental agency charged with a substantial responsibility and involving a wide span of disciplinary expertise. For instance, P5 wrote, "All of the organizations that fall under the Department of Homeland Security are just people doing their jobs" 
(P5). On the other hand, as P11 noted, "I was simply unaware of all the agencies involved in homeland security. I thought it was a bunch of guys in a large room sitting around looking security cameras" (P11).

It needs mentioning, that one might initially read the DHS mission of "all hazards" protection without really understanding the context of "all" being used (Noftsinger et al., 2007). In addition, as many participants noted, before the course, they understood the role of homeland security to be part of the Department of Defense mission. For example, as P7 stated, "I think I confused them most of my life with the Department of Defense as far as the military aspect of it, while Homeland Security is more civilian based" (P7).

Many of the participants reflected on DHS being an umbrella covering many organizations and responsibilities, such as P2 who noted, "It's different organizations within the homeland security umbrella that help to keep us safe on so many levels" (P2). The realization of the magnitude of DHS's responsibility and mission was expressed in the writings of the participants, who referenced roles such as TSA agents to cyber security experts. Moreover, the role of immigration policy and enforcement seemed more complex than the learners' understanding at the beginning of the course. Realization was synthesized through reflection, which focused the learners toward the evaluation of their experiences and the possible variations of the experiences (Courtney et al., 1998). However, this reflection occurred across time when the learners compared the experiential variation of past and present engagement with the issues associated with the course.

\section{Appreciation for New Understandings}

In all levels of education, the affective domain of learning is the most difficult to assess and evaluated (Dufner, Arslan, Hagemeyer, Schönbrodt, \& Denissen, 2015). The subject matter of homeland security proved to be significantly more complex and wide-reaching than the learners initially believed. Qualitative inquiry allowed us to "see" how and why the reflection processes engages people's affect (Courtney et al., 1998; Maxfield, \& Fisher, 2012; Van Manen, 2018). The engagement in affect could not be easily measured, but it was qualitatively expressed by learners to facilitate a relatively stable change in attitudes and beliefs about various homeland security issues. For example, P1 wrote, "we should find smarter ways to stop crime" (P1), P6 reflected "Homeland Security just seems crucial to me" (P6), and P11 noted "It is much clearer to me that we are in a constant struggle to better our nation's security" (P11).

\section{New Areas of Curiosity}

Complex social and political issues seem to have never-ending problems to be addressed and evolve ahead of our ability to solve them. As mentioned above, wisdom is gained through in-depth study and reflection. For example, issues like immigration, cyberattacks, and globalism led learners to become concerned on a broader social, political and existential framework. For example, P1 noted, "There is so much involved from beginning to end and it's interesting to me" (P1). By looking at the reflective writings of the participants, the "whole" of homeland security seems to have grown for each of these learners and the "parts" became many and interconnected. Discovering the complexity and magnitude of homeland security seems to have influenced each of the 
participants to find homeland security a salient and ever-important subject matter and to take it personally. P11 sums this up by writing, "I think we are getting more and more vulnerable as we become more technologically advanced. If we fail to maintain our hyper vigilance for and become accustomed to the simple things in life it will be destructive" (P11).

As researchers, we do not consider it a stretch to say the evidence shows in this study that the homeland security learners actually acquired wisdom through engaging and reflecting on the course content. Therefore, reflective strategies employed by the instructors prompted and required learners to have a higher level of thinking on the course materials (Russell \& Fisher, 2014). A long-standing view is that deep and sustained reflection on information leads to truth, wisdom, and embraced as personal knowledge (Chu, 1990; Heidegger, 2008; Polanyi, 1975). Therefore, course readings and assignments in homeland security should involve a variety of disciplinary perspectives, historical and cultural contexts, and seminal works that evoke deep reflective thinking and writing. The reflective writing process helps develop the student's understanding of that which he or she is studying (Van Manen, 2018). This development of knowledge can operate both explicitly and tacitly in the manner in which the learner engages his or her real-world problems, both personally and professionally (Polanyi, 1975). Reflective writing is an experiential way for a person to enter the hermeneutic circle, going from the whole to the parts and back again to the whole, which facilitates the reflections of evaluation and variation (Courtney et al., 1998; Maxfield, \& Fisher, 2012; Van Manen, 2018). We can see by the data the participants may not have had such an educational experience through lecture, reading, and testing in a traditional learning model. Rather, the asynchronous online learning venue with reflective assignments involved resulted in an appreciation for the wisdom gained in the process. This was founded upon the learners' realization of an appreciation of new understandings; that is, homeland security is complex and everybody's responsibility.

\section{CONCLUSION}

The purpose of the research study was to spotlight the influence an asynchronous online homeland security course had on students. Using the reflective writing of the study's participants, the researchers were able to analytically generalize and delineate upon three thematic findings that arose from the data analysis as they pertain specifically to the introductory homeland security course being studied (Yin, 2018). The emergent themes discovered were (a) a realization of responsibility and mission, (b) an appreciation for new understandings, and (c) new areas of curiosity. These themes seemingly support Goldberg's (2012) argument that reflective writing in homeland security education leads to a deeper and more meaningful understanding of the topics. The themes discovered in this study hold promise to serve as traits when constructing future homeland security and emergency management course offerings; however, as noted above, in order to validate these traits more research is needed. 


\section{Limitations and Future Research}

There are five limitations associated with this study. The first is the reliance upon the writings of the participants, thus limiting the scope of data to only what each individual participant was willing to share. The second limitation builds on the first and that was the use of existing data without follow-up interviews. This limitation hampers the ability of researchers to ask follow-up questions in order to glean a richer understanding of the coursework's influence. The third limitation was the ability of the individual researchers to use inductive reasoning and to separate their own biases when analyzing the data. The fourth limitation was that of a single case study using one course during one semester. The fifth limitation is the research is limited to one case study on the use of reflection in homeland security education. Because a qualitative approach was used and results may be tentative, further study is needed to confirm the propositions and develop better understanding of critical thinking and reflection in the learning process.

Future research is needed to build upon this study's findings that involves interviews with participants. Individual learners may be influenced by media reporting of future incidents; therefore, it is recommended that a future study considers both coursework and current events. In addition, the researchers recommend that future research is needed to look at more than one course over multiple semesters so as to consider the societal influences and experiences. In addition, the researchers note that further study regarding non-affiliated traditional students is needed in order to understand the influence reflection has on students lacking emergency services experiences.

\section{REFERENCES}

Basit, T. (2003). Manual or electronic? The role of coding in qualitative data analysis. Educational research, 45(2), 143-154.

Bellavita, C. (2008). Changing homeland security: What is homeland security? Homeland Security Affairs, 4(2), 1-30.

Bellavita, C., \& Gordon, E. M. (2006). Changing homeland security: Teaching the core. Naval Postgraduate School Monterey CA Center of Homeland Defense and Security.

Borja, E. C. (2008). Brief documentary history of the department of homeland security, 2001-2008. US Department of Homeland Security, History Office.

Brockbank, A., \& McGill, I. (1998). Facilitating reflective learning in higher education. Society for Research into Higher Education. Buckingham: Open University.

Bullock, J., Haddow, G., \& Coppola, D. P. (2011). Introduction to homeland security: Principles of all-hazards risk management. Oxford: Butterworth-Heinemann.

Burbach, M. E., Matkin, G. S., \& Fritz, S. M. (2004). Teaching critical thinking in an introductory leadership course utilizing active learning strategies: A confirmatory study. College Student Journal, 38(3), 482-494.

Caruson, K., \& MacManus, S. A. (2006). Mandates and management challenges in the trenches: An intergovernmental perspective on homeland security. Public Administration Review, 66(4), 522-536. 
Chesley, A., Coots, M. W., Jackson, A., Knapp, S., Mentzer, N., \& Laux, D. (2018). The Impacts of integrating introductory composition, communication, and design thinking courses. Journal of Technology Education, 30(1), 66-82.

Chu, H. (1990). Learning to be a sage: Selections from the conversations of Master Chu, arranged topically. D.K. Gardener (Trans.). Oakland, CA: U. of California.

Comiskey, J. (2015). How do college homeland security curricula prepare students for the field? Journal of Homeland Security Education, 4, 20-40.

Corbin, J., \& Strauss, A. (2008). The basics of qualitative research. Thousand Oaks, CA: Sage.

Courtney, J., Croasdell, D., \& Paraadice, D. (1998). Inquiring organizations. Australian Journal of Information Systems, 6(1).

Coyne, A. (1984). Introduction to inductive reasoning. Lanham, MD: U. Press of US.

Dewey, J. (1938/2007). Experience and education. NY: Simon and Schuster.

Drabek, T. (2009). Emergency management and homeland security curricula: Context, Cultures, and constraints. Journal of Emergency Management 5, 33- 42.

Dufner, M., Arslan, R. C., Hagemeyer, B., Schönbrodt, F. D., \& Denissen, J. J. (2015). Affective contingencies in the affiliative domain: Physiological assessment, associations with the affiliation motive, and prediction of behavior. Journal of Personality and Social Psychology, 109(4), 662.

Federal Emergency Management Agency (FEMA). (2018). The college list: Colleges, universities, and institutions offering emergency management courses. Retrieved from https://training.fema.gov/hiedu/collegelist/.

Fusch, P. I., \& Ness, L. R. (2015). Are we there yet? Data saturation in qualitative research. The qualitative report, 20(9), 1408-1416.

Goldberg, K. (2012). Reflective journaling: Building bridges between theory and practice. Journal of Homeland Security Education, 1, 63-69.

Goodyear, P. (2015). Teaching as design. Herdsa review of higher education, 2, 27-50.

Gurung, R. A. R., Hackathorn, J., Enns, C., Frantz, S., Cacioppo, J. T., Loop, T., \& Freeman, J. E. (2016). Strengthening introductory psychology: A new model for teaching the introductory course. The American Psychologist, (2), 112.

Heidegger, M. (2008). Ontology - The hermeneutics of facticity. J. van Buren (Trans.). Bloomington, IN: Indiana University.

Hoisch, T. D., \& Bowie, J. I. (2010). Assessing factors that influence the recruitment of majors from introductory geology classes at Northern Arizona University. Journal of Geoscience education, 58(3), 166-176.

Hughes, R. (1983). The non-traditional student in higher education: A synthesis of the literature. Naspa Journal, 20(3), 51-64.

Kemmis, S. (1985). Action research and the politics of reflection. In D. Boud, R. Keogh, \& Walker, D. Reflection: Turning experience into learning (pp. 139-163). New York, NY: Routledge. 
Kennedy, M. (1979). Generalizing from single case studies. Eval. Quart, 3(4), 661-678.

Kiltz, L. (2009). Developing critical thinking skills in homeland security and emergency management courses. Journal of Homeland Security and Emergency Management, 6(1).

Mason, M. (2010). Sample size and saturation in PhD studies using qualitative interviews. Qualitative Social Research, 11(3), Art 8.

Maxfield, R. J., \& Fisher, J. R. (2012). Employing critical reflection in an online emergency services course. Journal of Homeland Security Education, 1(1) 26-40.

Mezirow, J. (1990). How critical reflection triggers transformative learning. Fostering Critical Reflection in Adulthood, 1(20), 1-6.

Moon, J. A. (1999). Reflection in learning and professional development: Theory and practice. London: Kogan Page Limited.

National Research Council (2005). Frameworks for higher education in homeland security. Washington, DC: The National Academies Press.

Noftsinger, J. B., Newbold, K. F., \& Wheeler, J. K. (2007). What is homeland security? In Understanding homeland security (pp. 27-53). NY: Palgrave Macmillan.

O'Neill, G., \& Noonan, E. (2011). Designing first year assessment strategically. Retrieved from http://eprints.teachingandlearning.ie/3350/1/O'Neill\%20and\%20Noonan\%202011.pdf.

Patton, M. Q. (2002). Qualitative research and evaluation methods. Thousand Oaks, CA: Sage.

Pelfrey, W. V., \& Kelley, W. D. (2011). Homeland security education: A way forward. Homeland Security Affairs, 9(3), 1-12.

Polanyi, M. (1975). Personal knowledge: Towards a post-critical philosophy. Chicago, IL: University of Chicago.

Russell, E. J., \& Fisher, J. R. (2014). The impressions of emergency services students in a homeland security course: The benefits of reflective thinking and journaling. Journal of Homeland Security Education, 3, 14-24.

Schön, D.A. (1987). Educating the reflective practitioner: Toward a new design for teaching and learning in the professions. San Francisco: Jossey-Bass.

Seawright, J., \& Gerring, J. (2008). Case selection techniques in case study research: A menu of qualitative and quantitative options. Political Res. Quarterly, 61(2), 294-308.

Stake, R. (1995). The art of case study research. Thousand Oaks, California: Sage.

Szenes, E., Tilakaratna, N., \& Maton, K. (2015). The knowledge practices of critical thinking. In M. Davies, \& R. Barnett (Eds.), The Palgrave handbook of critical thinking in higher education (pp. 573-591). Palgrave Macmillan, New York.

Van Manen, M. (2018). Researching lived experience: Human Science for an action sensitive pedagogy. New York, NY: Routledge.

Yin, R. (2018). Case study research: Design and method. Thousand Oaks, CA: Sage.

Young, M., \& Warren, D. L. (2011). Encouraging the development of critical thinking skills in the introductory accounting courses using the challenge problem approach. Issues in Accounting Education, 26(4), 859-881. 